\title{
Morpho-agronomic performance of vetch species and their accessions grown under nitosol and vertisol conditions in the central highlands of Ethiopia
}

Gezahagn Kebede* (D)

\begin{abstract}
Background: Vetch is one of the promising forage legumes to mitigate the existing critical feed shortage problem in the Ethiopian highlands. The study was conducted to describe the morphological and agronomical traits and to examine the performances of vetch species and their accessions under nitosol and vertisol conditions in the central highlands of Ethiopia.

Results: The result indicated that days to forage and seed harvest and plant height varied $(P<0.05)$ among vetch species and their accessions at both locations. Vicia narbonensis and Vicia sativa were early maturing; Vicia dasycarpa and Vicia atropurpurea were intermediate; and Vicia villosa was considered as late-maturing types of vetch species. Early-maturing vetch species and their accessions had comparatively higher biomass production rate, while latematuring species and their accessions had lower biomass production rate at both locations. On the other hand, intermediate-to-late-maturing vetch species and their accessions gave relatively better forage dry matter yield than early-maturing vetch species and their accessions at both locations. Early-maturing vetch species and their accessions had comparatively shorter grain filling period and higher grain sink filling rate than intermediate-to-late-maturing species and their accessions. Vetch species and their accessions which have an erect growth habit and early maturity had comparatively higher thousand seed weight than creeping growth habit and intermediate-to-late maturity vetch species and their accessions.
\end{abstract}

Conclusions: Generally, vetch species and their accessions had different growth features, phenology, forage and seed productivity. The generated information on vetch species and their accessions in this study gives a base for future compatibility study of cereals and non-legume forage crops. Among vetch species and their accessions, Vicia villosa, Vicia dasycarpa and Vicia atropurpurea species and their accessions have a potential for integration with other crops. However, the selected species and their accessions should be tested by integrating with different crops to come up with better recommendation to solve the feed problem of the Ethiopian highlands.

Keywords: Accessions, Forage yield, Growth habit, Maturity, Seed yield, Vetch species 


\section{Background}

The Ethiopian highlands, above 1500 masl, receive more than $700 \mathrm{~mm}$ annual rainfall and have a mean daily temperature of less than $20^{\circ} \mathrm{C}$ [1]. About $88 \%$ of the human population, $70 \%$ of cattle and sheep, $30 \%$ of goats and $80 \%$ of equines are found in this region [2]. The central highland of Ethiopia is characterized by crop-livestock mixed farming systems. Livestock is an integral component for most of the agricultural activities in the country. The share of livestock sub-sector in the national economy is estimated to be $12-16 \%$ to the total gross domestic product (GDP), 30-35\% to the agricultural GDP [3], 19\% to the export earnings [4], and $31 \%$ of the total employment [5]. Despite enormous contribution of livestock to the livelihood of farmers, availability of poor quality feed resources remains to be the major bottleneck to livestock production in the highlands of Ethiopia [6]. Traditional livestock production system mainly depends upon poor pasturelands and crop residues which are usually inadequate to support reasonable livestock production [7]. These feed resources are high in fiber, with low-tomoderate digestibility and low levels of nitrogen [8]. Their crude protein and neutral detergent fiber content ranges between $2.5-27.5$ and $72.6-77.8 \%$, respectively. Such low-quality feeds are associated with a low voluntary intake, thus resulting in insufficient nutrient supply, low productivity and even weight loss [9]. Currently, with the rapid increase in human population and increasing demand of food, grazing lands are steadily shrinking being converted to arable lands and availability of adequate feeds has become a major setback to increased livestock production [10]. Berhanu et al. [11] reported that improved nutrition through adoption of sown forage could substantially increase livestock productivity.

Among many annual forage legumes, adaptation of vetch is better and promising than the others in the Ethiopian highlands. Vetch is an annual forage legume widely adapted to the highlands of Ethiopia [12]. One of its species, Vicia atropurpurea, can perform better in the warmer areas like Bako, while others also can grow, but their performance is relatively low compared to cooler areas. It grows well on the reddish brown clay soils and the black soils of the highland areas. It has been grown successfully in areas of acid soil with $\mathrm{pH}$ of 5.5-6 [13]. Forage legumes like vetch are rich sources of $\mathrm{N}$ for livestock with cheaper prices compared to concentrates especially in developing countries [14]. Getnet and Ledin [15] also found that vetch has a higher crude protein content compared to many other tropical herbaceous legumes. Integration of forage legumes into the cereal-based cropping system through different methods is one of the strategic interventions for optimizing the productivity of a given land use system. Before integration of forage legumes with different methods, study on plant height, days to maturity, growth habit and other characteristics of forage legumes are vital for selection of the companion crops or mixtures for good compatibility and improved yields of companion crops without significant effect of one on the other. Previous evaluations of vetches were done mainly on environmental adaptation and biomass yield, but there is no wide assessment of accessions of different vetch species with respect to growth features, forage and seed productivity, forage quality and digestibility. Accordingly, there is a need to evaluate vetch for basic quantitative traits to address the feed demand of mixed farming systems. Therefore, this study was conducted to describe the morphological and agronomical traits and to examine the performances of vetch species and their accessions under nitosol and vertisol conditions in the central highlands of Ethiopia.

\section{Methods \\ Descriptions of the test environments}

The experiment was conducted at Holetta Agricultural Research Center (HARC) and Ginchi subcenter during the main cropping season of 2009 under rain fed condition. HARC is located at $9^{\circ} 00^{\prime} \mathrm{N}$ latitude, $38^{\circ} 30^{\prime} \mathrm{E}$ longitude at an altitude of $2400 \mathrm{~m}$ above sea level. It is $34 \mathrm{~km}$ west of Addis Ababa on the road to Ambo and is characterized with the long-term (30 years) average annual rainfall of $1055.0 \mathrm{~mm}$, average relative humidity of $60.6 \%$ and average maximum and minimum air temperature of $22.2{ }^{\circ} \mathrm{C}$ and $6.1{ }^{\circ} \mathrm{C}$, respectively. The rainfall is bimodal, and about $70 \%$ of the precipitation falls in the period from June to September, while the remaining 30\% falls in the period from March to May [16]. The soil type of the area is predominantly red nitosol, which is characterized by an average organic matter content of $1.8 \%$, total nitrogen $0.17 \%, \mathrm{pH} 5.24$ and available phosphorus $4.55 \mathrm{ppm}$ [17]. Ginchi subcenter is located at $75 \mathrm{~km}$ west of Addis Ababa in the same road to Ambo. It is situated at $9^{\circ} 02^{\prime} \mathrm{N}$ latitude and $38^{\circ} 12^{\prime} \mathrm{E}$ longitude with an elevation of $2200 \mathrm{~m}$ above sea level and characterized with the long-term (30 years) average annual rainfall of $1095.0 \mathrm{~mm}$, average relative humidity of $58.2 \%$ and average maximum and minimum air temperature of $24.6{ }^{\circ} \mathrm{C}$ and $8.4{ }^{\circ} \mathrm{C}$, respectively. The site has a bimodal rainfall pattern with the main rain from June to September and short rain from March to May [16]. The soil of the area is predominately black clay vertisol with organic matter content of $1.3 \%$, total nitrogen $0.13 \%, \mathrm{pH} 6.5$ and available phosphorus $16.5 \mathrm{ppm}$ [18]. The map of the study areas is given in Fig. 1 . 


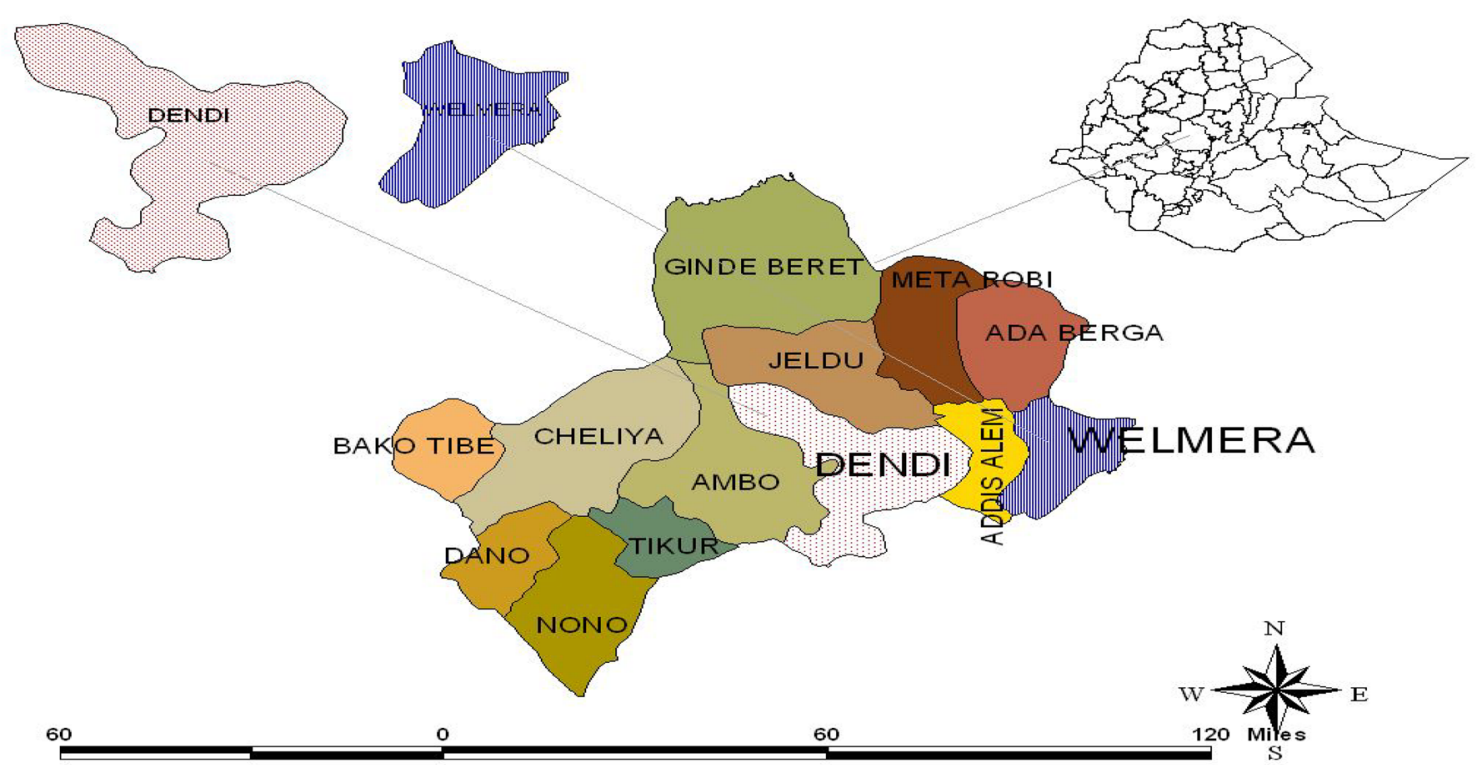

Fig. 1 Map of the experimental sites, at Holetta (Welmera) and Ginchi (Dendi) in the central highlands of Ethiopia

\begin{tabular}{|c|c|c|c|c|c|}
\hline Nos. & Species & Accessions & Nos. & Species & Accessions \\
\hline 1 & Vicia sativa & 64266 & 11 & Vicia villosa & 2434 \\
\hline 2 & Vicia sativa & 61904 & 12 & Vicia villosa & 2446 \\
\hline 3 & Vicia sativa & 61744 & 13 & Vicia narbonensis & 2384 \\
\hline 4 & Vicia sativa & 61509 & 14 & Vicia narbonensis & 2387 \\
\hline 5 & Vicia sativa & 61039 & 15 & Vicia narbonensis & 2376 \\
\hline 6 & Vicia sativa & 61212 & 16 & Vicia narbonensis & 2392 \\
\hline 7 & Vicia villosa & 2565 & 17 & Vicia narbonensis & 2380 \\
\hline 8 & Vicia villosa & 2450 & 18 & Vicia dasycarpa & Namoi \\
\hline 9 & Vicia villosa & 2424 & 19 & Vicia dasycarpa & Lana \\
\hline 10 & Vicia villosa & 2438 & 20 & $\begin{array}{l}\text { Vicia atropur- } \\
\text { purea }\end{array}$ & Atropurpurea \\
\hline
\end{tabular}

\section{Experimental treatments and design}

The study was executed using 20 accessions from five vetch species (Table 1). All accessions of Vicia narbonensis, Vicia villosa and Vicia sativa were introduced from International Center for Agricultural Research in the dry areas; and Vicia dasycarpa and Vicia atropurpurea accessions were initially introduced from Australia. Most of the accessions of vetch species were selected on the basis of their adaptation to the central highlands of Ethiopia from the previous screening trials. The experimental fields were prepared following the recommended tillage practice, and a fine seed bed was used at planting. At Ginchi site, sowing was done on camber beds to improve drainage and reduce water-logging problems of vertisol. The experiment was conducted on a randomized complete block design with three replications. Seeds were drilled in rows of $30 \mathrm{~cm}$ on a plot size of $2.4 \mathrm{~m} \times 4 \mathrm{~m}=9.6 \mathrm{~m}^{2}$, which consisted of 8 rows. Based on experimental design, each treatment was assigned randomly to the experimental units within a block. The species were sown according to their recommended seeding rates: $25 \mathrm{~kg} / \mathrm{ha}$ for Vicia villosa, Vicia dasycarpa and Vicia atropurpurea; $30 \mathrm{~kg} / \mathrm{ha}$ for Vicia sativa; and $75 \mathrm{~kg} / \mathrm{ha}$ for Vicia narbonensis. At sowing, $100 \mathrm{~kg} / \mathrm{ha}$ diammonium phosphate fertilizer was uniformly applied for all treatments at both locations. The first hand weeding was made 30 days after crop emergence, and the second weeding was done 30 days after the first weeding. The two rows next to the guard rows were used for determination of number of pods per plant, pod length per plant and number of seeds per pod. Similarly, the two rows prior to the inner two rows were used to evaluate proportion of morphological fractions, plant height, forage and morphological fraction yields. The remaining two rows were used for seed yield determination.

\section{Data collection}

Description of data collection procedure is presented in Table 2. Data on morpho-agronomic traits for vetch species and their accessions were collected on plot and plant basis according to Getnet [19].

\section{Statistical analysis}

Analysis of variance procedures of SAS general linear model was used to compare treatment means [20]. The $F$-test for homogeneity of variance was carried, and its 
Table 2 Descriptions of morpho-agronomic traits of vetch species and their accessions

\begin{tabular}{|c|c|c|}
\hline SN & Traits & Descriptions \\
\hline 1 & Days to forage harvesting (days) & Counted from days to emergence to days of half (50\%) of the plot/plants set flower \\
\hline 2 & Days to seed harvesting (days) & Counted from days to emergence to days to seed maturity \\
\hline 3 & Un-stretched plant height (cm) & Measured from the ground to the tip of plant at forage harvesting stage \\
\hline 4 & Stretched plant height (cm) & Measured from the ground to the stretched tip of the plant at forage harvesting stage \\
\hline 5 & Biomass production rate $\left(\mathrm{kg} \mathrm{ha}^{-1}\right.$ day $\left.^{-1}\right)$ & Computed by dividing the above ground biomass yield to the number of days to forage harvesting \\
\hline 6 & Forage dry matter yield (t/ha) & $\begin{array}{l}\text { Determined by converting the harvested fresh biomass yield into dry matter yield after oven-drying for } \\
24 \mathrm{~h} \text { at a temperature of } 105^{\circ} \mathrm{C}\end{array}$ \\
\hline 7 & Grain filling period (days) & Counted from days to flower initiation to days to physiological maturity \\
\hline 8 & Grain sink filling rate $\left(\mathrm{kg} \mathrm{ha}^{-1} \mathrm{day}^{-1}\right)$ & Computed as the ratio of grain yield to number of days from flower initiation to physiological maturity \\
\hline 9 & Number of pods per plant (number) & Counted by uprooting six plants from each experimental plot \\
\hline 10 & Pod length $(\mathrm{cm})$ & Measured the length by taking six pods per plant \\
\hline 11 & Number of seeds per pod (number) & Counted the seeds by taking six pods per plant from each plot \\
\hline 12 & Grain yield (t/ha) & $\begin{array}{l}\text { The plants harvested from ground level at the optimum seed harvesting time and oven-dried at } 100^{\circ} \mathrm{C} \\
\text { for } 48 \mathrm{~h} \text { to adjust the moisture content to the level of } 10 \%\end{array}$ \\
\hline 13 & Thousand seed weight (gm) & Thousand seeds counted and oven-dried at $100^{\circ} \mathrm{C}$ for $48 \mathrm{~h}$ to determine the weight \\
\hline
\end{tabular}

value was computed as the ratio of the two error mean squares: the larger error mean square in the numerator and the smaller error mean square in the denominator [21]. According to Gomez and Gomez [21], the error variances could be considered homogeneous when the error mean square ratio was not greater than the tabulated $F$ value. Logarithmic transformation was used for data which could not exhibit homogeneity of variance for agro-morphological parameters according to Gomez and Gomez [21]. Duncan's multiple range test at 5\% significance was used for comparison of means. The data were analyzed using the following model. $Y_{i j k}=\mu+T_{i}+L_{j}+(T L)_{i j}+B_{k(j)}+e_{i j k}$, where $Y_{i j k}=$ measured response of treatment $i$ in block $k$ of location $j, \mu=$ grand mean, $T_{i}=$ effect of treatment $\mathrm{i}$, $L_{j}=$ effect of location $j, T L=$ treatment and location interaction, $B_{k(j)}=$ effect of block $k$ in location $j$ and $e_{i j k}=$ random error effect of treatment $i$ in block $k$ of location $j$.

\section{Results and discussion Weather of the experimental sites}

The 10-year average annual rainfall and average maximum and minimum daily air temperatures, relative humidity and evaporation values at the experimental site of Holetta were $962.7 \mathrm{~mm}, 22.6{ }^{\circ} \mathrm{C}, 6.0{ }^{\circ} \mathrm{C}, 53.5 \%$ and $7.3 \mathrm{~mm}$, respectively. The respective values for Ginchi were $1032.0 \mathrm{~mm}, 24.4{ }^{\circ} \mathrm{C}, 8.8{ }^{\circ} \mathrm{C}, 58.5 \%$ and $5.4 \mathrm{~mm}$. During the cropping season, total rainfall, mean maximum and minimum daily air temperatures, relative humidity and evaporation values were 728.8 and $870.6 \mathrm{~mm} ; 23.2$ and $24.5{ }^{\circ} \mathrm{C} ; 7.1$ and $9.1{ }^{\circ} \mathrm{C}$; 59.4 and 55.0\%; 3.8 and $4.6 \mathrm{~mm}$ for Holetta and Ginchi testing sites, respectively. During the main rainy season, especially in the month of June, substantial shortage of rainfall was recorded for both sites as compared with the long-term observations, which resulted in delayed sowing. Compared to the long-term average, the rainfall was lower during the growing season, but the minimum and maximum air temperatures were relatively higher in both testing sites. In general, mean of all recorded weather elements except relative humidity values was relatively lower at Holetta as compared to that of Ginchi during the experimental year, 2009. Total monthly rainfall and average maximum and minimum daily air temperatures during the experimental period at the trial sites of Holetta and Ginchi are shown in Figs. 2 and 3.

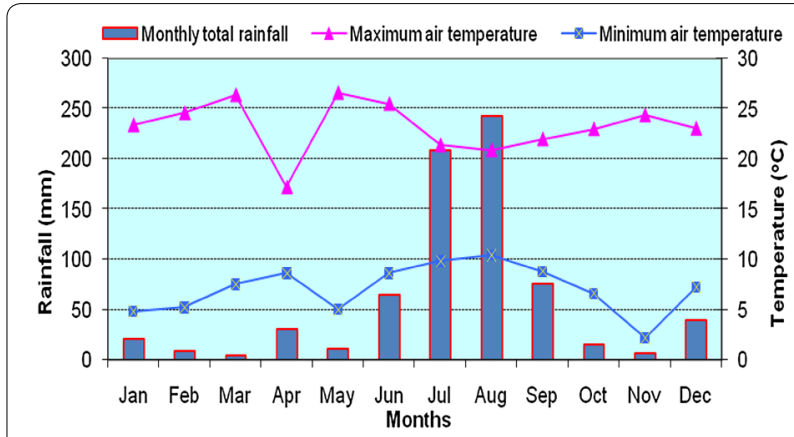

Fig. 2 Clima-diagram during the experimental period (2009) at the trial site, Holetta 


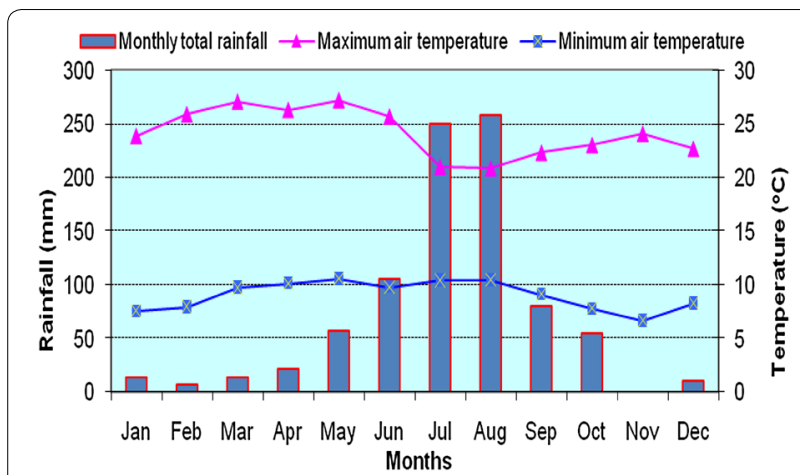

Fig. 3 Clima-diagram during the experimental period (2009) at the trial site, Ginchi

\section{Physicochemical properties of soils of the experimental sites}

Soil physicochemical properties of the two experimental sites are presented in Table 3. The soil is clay in texture at both locations. Soil texture or the relative amounts of sand, silt and clay play a very important role in plant nutrition due to its effect on the ability to retain both water and nutrients [22]. The total nitrogen and organic carbon contents of the soils were comparatively higher at Holetta, while $\mathrm{pH}$, available phosphorus and cationexchange capacity (CEC) were relatively higher at Ginchi, and the same result was also reported by Muluneh [23]. Total nitrogen content at Ginchi was reduced by leaching, runoff and water-logging (denitrification) processes. Under anaerobic condition, the microorganism decompose high amount of organic matter $(\mathrm{OM})$ to get the required amount of energy, but its accumulation is high under aerobic, acidic and cold environment because of low decomposition rate due to low activity of microorganism [22]. Soil pH affects the availability of the nutrients in the soil. Lower $\mathrm{pH}$ generally causes lower CEC, and P-fixation is affected by amount of $\mathrm{Fe} / \mathrm{Al}$ oxides, clay mineral types, soil $\mathrm{pH}$, organic matter and moisture content of the soil [24]. The total nitrogen, organic carbon, available phosphorus and $\mathrm{pH}$ of the soil slightly increased after harvesting of the crops. The total nitrogen, organic carbon, available phosphorus and CEC decreased, while $\mathrm{pH}$ increased with increasing soil depth.

\section{Days to forage and seed harvest}

Days to forage harvest for species of vetch showed significant $(P<0.05)$ difference at both locations (Table 4$)$. Though Ginchi site is relatively warmer than Holetta,

Table 4 Least square means for days to forage and seed harvest of five vetch species grown at Holetta and Ginchi

\begin{tabular}{lccccc}
\hline \multirow{2}{*}{ Species } & \multicolumn{2}{l}{$\begin{array}{l}\text { Days to forage } \\
\text { harvest }\end{array}$} & & \multicolumn{2}{l}{ Days to seed harvest } \\
\cline { 2 - 3 } \cline { 6 - 6 } \cline { 5 - 6 } & Holetta & Ginchi & & Holetta & Ginchi \\
\hline Vicia sativa & $96.1^{\mathrm{c}}$ & $107.9^{\mathrm{c}}$ & & $119.7^{\mathrm{c}}$ & $151.3^{\mathrm{b}}$ \\
Vicia villosa & $112.2^{\mathrm{a}}$ & $117.4^{\mathrm{b}}$ & & $149.9^{\mathrm{a}}$ & $157.9^{\mathrm{a}}$ \\
Vicia narbonensis & $83.3^{\mathrm{d}}$ & $96.8^{\mathrm{d}}$ & & $113.5^{\mathrm{d}}$ & $134.6^{\mathrm{c}}$ \\
Vicia dasycarpa & $105.3^{\mathrm{b}}$ & $113.0^{\mathrm{b}}$ & & $129.7^{\mathrm{b}}$ & $156.8^{\mathrm{ab}}$ \\
Vicia atropurpurea & $108.3^{\mathrm{a}}$ & $124.7^{\mathrm{a}}$ & & $135.3^{\mathrm{b}}$ & $159.3^{\mathrm{a}}$ \\
Mean & 101.0 & 112.0 & & 129.6 & 152.0 \\
CV (\%) & 0.68 & 1.01 & & 4.08 & 4.05 \\
$R^{2}$ & 0.94 & 0.76 & & 0.9 & 0.73 \\
\hline
\end{tabular}

Means followed by a common superscript letters within a column are not significantly different from each other at $P<0.05$

$\checkmark=$ Log transformation

Table 3 Physicochemical properties of the soil at the experimental sites at Holetta, red nitosol and Ginchi clay vertisol before planting and after harvesting

\begin{tabular}{|c|c|c|c|c|c|c|c|c|}
\hline \multirow[t]{3}{*}{ Parameters } & \multicolumn{4}{|c|}{ Before planting } & \multicolumn{4}{|c|}{ After harvesting } \\
\hline & \multicolumn{2}{|c|}{ Holetta } & \multicolumn{2}{|c|}{ Ginchi } & \multicolumn{2}{|c|}{ Holetta } & \multicolumn{2}{|l|}{ Ginchi } \\
\hline & $0-15$ & $15-30$ & $0-15$ & $15-30$ & $0-15$ & $15-30$ & $0-15$ & $15-30$ \\
\hline $\mathrm{pH}\left(1: 1 \mathrm{H}_{2} \mathrm{O}\right)$ & 5.43 & 5.61 & 6.20 & 6.23 & 5.49 & 5.59 & 6.23 & 6.25 \\
\hline Total OC (\%) & 2.37 & 2.23 & 1.31 & 1.26 & 2.41 & 2.06 & 1.37 & 1.35 \\
\hline Total N (\%) & 0.21 & 0.20 & 0.09 & 0.08 & 0.22 & 0.20 & 0.09 & 0.08 \\
\hline Available $P(\mathrm{ppm})^{\mathrm{b}}$ & 5.40 & 4.67 & 11.60 & 9.60 & 7.13 & 5.60 & 13.73 & 13.70 \\
\hline CEC (meg/100 g) & 26.07 & 25.53 & 49.94 & 43.45 & 25.82 & 25.17 & 49.62 & 49.55 \\
\hline Sand (\%) & 13.33 & 13.75 & 15.83 & 15.83 & 15.83 & 15.83 & 17.08 & 15.00 \\
\hline Silt (\%) & 26.25 & 24.58 & 15.42 & 15.42 & 26.25 & 24.17 & 14.17 & 17.08 \\
\hline Clay (\%) & 60.42 & 63.33 & 68.75 & 68.75 & 57.92 & 60.00 & 68.75 & 67.92 \\
\hline Textural class & Clay & Clay & Clay & Clay & Clay & Clay & Clay & Clay \\
\hline
\end{tabular}

\footnotetext{
a Organic carbon
}

b Bray II method 
early maturity for forage and seed was recorded at Holetta than Ginchi. This could be due to high and extended rainfall at Ginchi during the cropping season that encouraged vegetative growth and delayed forage and seed harvesting stages. On average, about 10 and 20 more days were required to harvest forage and seed yield, respectively, at Ginchi compared to Holetta. This indicates different responses of the tested species for these important agronomic traits at both locations. The result indicated that 83.3 to 112.2 and 96.8 to 124.7 days were required after emergence of the seedlings for forage harvesting at Holetta and Ginchi, respectively. Vicia narbonensis was significantly early $(P<0.05)$, while Vicia atropurpurea significantly late $(P<0.05)$ for forage harvest at both locations. Getnet et al. [25] also reported that species such as Vicia narbonensis and Vicia sativa are relatively early maturing than other vetch species. The variation in forage maturity is an important agronomic trait to select companion crops for maximum production. Getnet et al. [25] also reported that days to maturity had an advantage of selecting companion or mixture crops that best synchronizes to the days to maturity for better compatibility and forage yield. Days to forage and seed harvest for accessions of vetch species also showed significant $(P<0.05)$ difference at Holetta and Ginchi (Table 5). Days to forage harvest ranged from 80.7 to 113.0 and 94.3 to 126.0 days after emergence of the seedlings at Holetta and Ginchi, respectively. Vicia sativa accessions (61904 and 64266), Vicia villosa accessions (2450/2424 and 2565), Vicia narbonensis accessions (2384/2392 and 2376) and Vicia dasycarpa (Namoi/ Lana and Lana) showed early maturity for forage harvest at Holetta and Ginchi, respectively. On the other hand, accessions 61039, 2565 and 2376 at Holetta and 61744, 2434 and 2384/2387 at Ginchi showed late maturity from species of Vicia sativa, Vicia villosa and Vicia narbonensis, respectively. Namoi matures lately than Lana for forage harvest at Ginchi, and atropurpurea showed early maturity for forage harvest at Holetta than Ginchi.

The days to seed maturity of vetch species also showed very similar trend to days to maturity for forage at both locations (Table 4). Vicia narbonensis showed significantly earlier $(P<0.05)$ than the remaining species at both locations. On the other extreme, Vicia villosa was

Table 5 Average days to forage and seed harvests of twenty accessions of vetch species grown at Holetta and Ginchi

\begin{tabular}{|c|c|c|c|c|c|c|}
\hline \multirow[t]{2}{*}{ Nos. } & \multirow[t]{2}{*}{ Species } & \multirow[t]{2}{*}{ Accessions } & \multicolumn{2}{|c|}{ Days to forage harvest } & \multicolumn{2}{|c|}{ Days to seed harvest } \\
\hline & & & Holetta & Ginchi & Holetta & Ginchi \\
\hline 1 & Vicia sativa & 64266 & $94.0^{\mathrm{e}}$ & $103.7^{\mathrm{ef}}$ & $119.3^{9}$ & $156.0^{\mathrm{ab}}$ \\
\hline 2 & V. sativa & 61904 & $92.7^{e}$ & $104.0^{\text {ef }}$ & $118.7^{9}$ & $155.3^{\mathrm{ab}}$ \\
\hline 3 & V. sativa & 61744 & $97.3^{d}$ & $112.3^{\text {cde }}$ & $121.3^{\mathrm{efg}}$ & $156.3^{\mathrm{ab}}$ \\
\hline 4 & V. sativa & 61509 & $97.0^{d}$ & $110.0^{\text {cde }}$ & $119.7^{9}$ & $155.3^{\mathrm{ab}}$ \\
\hline 5 & V. sativa & 61039 & $99.3^{d}$ & $109.3^{\text {de }}$ & $118.7^{9}$ & $138.0^{c}$ \\
\hline 6 & V. sativa & 61212 & $96.0^{\text {de }}$ & $108.0^{\mathrm{cd}}$ & $120.3^{\mathrm{fg}}$ & $147.0^{b}$ \\
\hline 7 & V. villosa & 2565 & $113.0^{\mathrm{a}}$ & $112.7^{c d}$ & $141.0^{b c}$ & $160.7^{\mathrm{a}}$ \\
\hline 8 & V. villosa & 2450 & $111.7^{\mathrm{a}}$ & $118.7^{\mathrm{abc}}$ & $152.3^{\mathrm{a}}$ & $158.7^{\mathrm{a}}$ \\
\hline 9 & V. villosa & 2424 & $111.7^{\mathrm{ab}}$ & $117.3^{\mathrm{abcd}}$ & $153.0^{\mathrm{a}}$ & $160.3^{\mathrm{a}}$ \\
\hline 10 & V. villosa & 2438 & $112.0^{\mathrm{a}}$ & $116.0^{\mathrm{bcd}}$ & $152.0^{\mathrm{a}}$ & $156.3^{\mathrm{ab}}$ \\
\hline 11 & V. villosa & 2434 & $112.0^{\mathrm{a}}$ & $126.0^{\mathrm{a}}$ & $153.7^{\mathrm{a}}$ & $157.7^{\mathrm{a}}$ \\
\hline 12 & V. villosa & 2446 & $112.7^{\mathrm{a}}$ & $113.7^{c d}$ & $147.3^{\mathrm{ab}}$ & $153.7^{\mathrm{ab}}$ \\
\hline 13 & V. narbonensis & 2384 & $80.7^{9}$ & $98.0^{\mathrm{fg}}$ & $114.0^{9}$ & $134.3^{c}$ \\
\hline 14 & V. narbonensis & 2387 & $82.0^{9}$ & $98.0^{\mathrm{fg}}$ & $113.0^{9}$ & $133.7^{c}$ \\
\hline 15 & V.narbonensis & 2376 & $88.7^{f}$ & $94.3^{9}$ & $113.0^{9}$ & $134.0^{c}$ \\
\hline 16 & V. narbonensis & 2392 & $80.7^{9}$ & $96.7^{\mathrm{fg}}$ & $113.7^{9}$ & $135.0^{c}$ \\
\hline 17 & V.narbonensis & 2380 & $84.7^{9}$ & $97.0^{\mathrm{fg}}$ & $114.0^{9}$ & $135.7^{c}$ \\
\hline 18 & V. dasycarpa & Namoi & $105.3^{c}$ & $115.7^{\mathrm{bcd}}$ & $129.3^{\text {def }}$ & $161.0^{\mathrm{a}}$ \\
\hline 19 & V. dasycarpa & Lana & $105.3^{c}$ & $110.3^{\text {cde }}$ & $130.0^{\text {de }}$ & $152.7^{\mathrm{ab}}$ \\
\hline \multirow[t]{4}{*}{20} & V. atropurpurea & Atropurpurea & $108.3^{b c}$ & $124.7^{\mathrm{ab}}$ & $135.3^{\mathrm{cd}}$ & $159.3^{\mathrm{a}}$ \\
\hline & & Mean & 99.3 & 109.3 & 129.0 & 150.1 \\
\hline & & CV (\%) & 0.53 & 0.93 & 4.15 & 3.27 \\
\hline & & $R^{2}$ & 0.97 & 0.85 & 0.93 & 0.87 \\
\hline
\end{tabular}

Means followed by a common superscript letters within a column are not significantly different from each other at $P<0.05$

$\downarrow=$ Log transformation 
significantly late $(P<0.05)$ for seed harvest at Holetta but not significantly late with Vicia dasycarpa and Vicia atropurpurea at Ginchi. According to Getnet et al. [25], Vicia narbonensis and Vicia sativa are early maturing; Vicia dasycarpa and Vicia atropurpurea are intermediate; and Vicia villosa is late-maturing species recommended and utilized in the highlands of Ethiopia. Phenology (earliness and lateness) of vetch species has a great effect on seed yield productivity. Vicia narbonensis, Vicia sativa and Vicia dasycarpa should be grown for seed production due to earliness to escape frost months, whereas latematuring species like Vicia villosa and Vicia atropurpurea should not be advisable to grow for seed purpose at Holetta. All vetch species should be grown for seed purpose at Ginchi. Seed shattering is the common characteristics of most annual forage legumes. The pods on the upper part of the plant are still at grain filling, while those of the lower pods have already reached maturity due to indeterminate growth nature of vetch species which makes seed harvesting stage quite difficult. Hence, seed loss due to shattering problem is very high in the field. However, harvesting of such legumes at optimum maturity period can reduce the loss of seed as well as the weed effect on the succeeding crop. Generally, establishment of seed maturity calendar based on genetic and environmental factors may reduce these problems.

\section{Plant height at forage harvest}

Plant heights (stretched and un-stretched) for vetch species at forage harvest showed variation $(P<0.05)$ at both locations (Table 6). The vetch species growth habit can be broadly grouped as erect, creeping or climbing. For instance, Vicia dasycarpa, Vicia villosa and Vicia atropurpurea have creeping or climbing growth habit, whereas Vicia narbonensis and Vicia sativa have an erect growth habit. Hence, due to these differences in growth habit, two types of plant heights (stretched and un-stretched) were taken to evaluate their height performance at both locations. The tallest stretched plant height at forage harvest was recorded for Vicia dasycarpa followed by Vicia villosa and Vicia atropurpurea at Holetta. At Ginchi, Vicia atropurpurea was the tallest followed by Vicia dasycarpa and Vicia villosa. On the other hand, Vicia sativa and Vicia narbonensis were the shortest at both testing sites. Similarly, plant heights (stretched and un-stretched) for accessions of vetch at forage harvest also showed significant $(P<0.05)$ difference at both locations (Table 7$)$. Among Vicia narbonensis accessions, 2387 was the shortest at both locations, whereas 2384 and 2380 were the tallest at Holetta and Ginchi, respectively. On the other hand, accession 2434 ( $V$. villosa) and atropurpurea ( $V$.

\section{Table 6 Least square means for stretched and un-stretched height at forage harvest of five vetch species grown at Holetta and Ginchi}

\begin{tabular}{lccccc}
\hline Species & \multicolumn{2}{c}{ Stretched height } & & \multicolumn{2}{c}{ Un-stretched height } \\
\cline { 2 - 3 } & Holetta & Ginchi & & Holetta & Ginchi \\
\hline Vicia sativa & $87.1^{\mathrm{b}}$ & $102.6^{\mathrm{b}}$ & & $62.2^{\mathrm{a}}$ & $51.9^{\mathrm{c}}$ \\
Vicia villosa & $138.3^{\mathrm{a}}$ & $155.2^{\mathrm{a}}$ & & $62.9^{\mathrm{a}}$ & $61.8^{\mathrm{b}}$ \\
Vicia narbonensis & $55.2^{\mathrm{c}}$ & $44.3^{\mathrm{c}}$ & & $49.3^{\mathrm{b}}$ & $37.2^{\mathrm{d}}$ \\
Vicia dasycarpa & $151.6^{\mathrm{a}}$ & $167.0^{\mathrm{a}}$ & & $63.2^{\mathrm{a}}$ & $71.3^{\mathrm{a}}$ \\
Vicia atropurpurea & $136.9^{\mathrm{a}}$ & $185.9^{\mathrm{a}}$ & & $62.2^{\mathrm{a}}$ & $66.5^{\mathrm{ab}}$ \\
Mean & 113.8 & 131.0 & & 60.0 & 57.7 \\
CV (\%) & 3.45 & 4.62 & & 12.94 & 13.64 \\
$R^{2}$ & 0.87 & 0.87 & & 0.46 & 0.73 \\
\hline
\end{tabular}

Means followed by a common superscript letters within a column are not significantly different from each other at $P<0.05$

$\diamond=$ Log transformation

atropurpurea) were the tallest stretched plant height at Holetta and Ginchi, respectively. When un-stretched plant height was measured, accession 61904 ( $V$. villosa) at Holetta and Lana ( $V$. dasycarpa) at Ginchi were the tallest. All Vicia narbonensis accessions gave the lowest $(P<0.05)$ stretched plant height at forage harvest at both locations. Among Vicia narbonensis accessions, the highest and lowest plant heights at forage harvest were recorded for 2384 and 2387 at Holetta while 2380 and 2387 at Ginchi, respectively. The average stretched plant height was higher at Ginchi compared to Holetta, which could be attributed to higher and extended rainfall and favorable growing conditions. In addition to genetic variability, soil fertility and environmental conditions could also contribute to the difference in height. There are different methods to integrate forage legumes with food crops especially with cereals. During integration, plant height as well as growth habit should be considered, because it has an impact on compatibility. Studies at Holetta showed that shorter oats varieties were more compatible with vetch than taller varieties regardless of other features such as soil fertility status and fertilizer application [19]. Methods of forage legumes integration with food crops varied with growth habit of the forage legumes. For instance, species which has an erect growth habit is more compatible with small cereals in intercropping/under-sowing systems, while creeping or climbing growth habit has better compatibility with large cereals in intercropping/undersowing systems. Generally, for good compatibility, plant height and growth habit of forage legumes should be considered for optimum yield of companion crops without significant effect of one on the other. 
Table 7 Average stretched and un-stretched plant heights $(\mathrm{cm})$ at forage harvesting stage of twenty accessions of vetch species grown at Holetta and Ginchi

\begin{tabular}{|c|c|c|c|c|c|c|}
\hline \multirow[t]{2}{*}{ Nos. } & \multirow[t]{2}{*}{ Species } & \multirow[t]{2}{*}{ Accessions } & \multicolumn{2}{|c|}{ Stretched height } & \multicolumn{2}{|c|}{ Un-stretched height } \\
\hline & & & Holetta & Ginchi & Holetta & Ginchi \\
\hline 1 & Vicia sativa & 64266 & $96.3^{c}$ & $103.3^{e}$ & $66.2^{\mathrm{ab}}$ & $60.1^{\text {bcde }}$ \\
\hline 2 & V. sativa & 61904 & $89.8^{c}$ & $102.5^{\mathrm{e}}$ & $71.3^{\mathrm{a}}$ & $54.3^{\text {cde }}$ \\
\hline 3 & V. sativa & 61744 & $84.8^{c}$ & $131.1^{\mathrm{cd}}$ & $62.1^{\mathrm{abcd}}$ & $51.0^{\text {def }}$ \\
\hline 4 & V. sativa & 61509 & $85.3^{c}$ & $120.3^{\text {de }}$ & $60.6^{\mathrm{abcd}}$ & $57.9^{\text {bcde }}$ \\
\hline 5 & V. sativa & 61039 & $73.7^{\mathrm{cd}}$ & $100.3^{e}$ & $45.9^{f}$ & $50.1^{\text {efg }}$ \\
\hline 6 & V. sativa & 61212 & $62.7^{c}$ & $57.7^{f}$ & $66.3^{\mathrm{ab}}$ & $37.8^{h}$ \\
\hline 7 & V. villosa & 2565 & $139.1^{\mathrm{ab}}$ & $133.1^{\mathrm{cd}}$ & $62.3^{\mathrm{abcd}}$ & $62.7^{\mathrm{abcd}}$ \\
\hline 8 & V. villosa & 2450 & $123.1^{b}$ & $144.0^{\mathrm{bcd}}$ & $64.7^{\mathrm{ab}}$ & $54.1^{\text {cde }}$ \\
\hline 9 & V. villosa & 2424 & $148.2^{\mathrm{a}}$ & $170.4^{\mathrm{ab}}$ & $59.6^{\text {abcde }}$ & $64.5^{\mathrm{abc}}$ \\
\hline 10 & V. villosa & 2438 & $119.3^{b}$ & $163.0^{\mathrm{ab}}$ & $60.9^{\mathrm{abcd}}$ & $61.5^{\mathrm{abcde}}$ \\
\hline 11 & V. villosa & 2434 & $160.9^{\mathrm{a}}$ & $157.4^{\mathrm{abc}}$ & $67.1^{\mathrm{ab}}$ & $66.2^{\mathrm{ab}}$ \\
\hline 12 & V. villosa & 2446 & $139.1^{\mathrm{ab}}$ & $158.9^{\mathrm{abc}}$ & $62.9^{a b c}$ & $61.7^{\mathrm{abcde}}$ \\
\hline 13 & V.narbonensis & 2384 & $60.7^{\text {de }}$ & $47.6^{f}$ & $54.1^{\text {bcdef }}$ & $39.5^{g^{h}}$ \\
\hline 14 & V.narbonensis & 2387 & $48.0^{\mathrm{e}}$ & $38.5^{f}$ & $43.3^{f}$ & $33.6^{h}$ \\
\hline 15 & V. narbonensis & 2376 & $54.8^{\mathrm{de}}$ & $45.6^{f}$ & $47.9^{e f}$ & $39.9^{g h}$ \\
\hline 16 & V. narbonensis & 2392 & $53.2^{\text {de }}$ & $41.4^{f}$ & $49.9^{\text {def }}$ & $31.9^{h}$ \\
\hline 17 & V. narbonensis & 2380 & $59.5^{\text {de }}$ & $48.3^{f}$ & $51.3^{\text {cdef }}$ & $41.1^{\text {fgh }}$ \\
\hline 18 & V. dasycarpa & Namoi & $149.2^{\mathrm{a}}$ & $159.2^{\mathrm{abc}}$ & $62.6^{\mathrm{abcd}}$ & $69.5^{\mathrm{ab}}$ \\
\hline 19 & V. dasycarpa & Lana & $153.9^{\mathrm{a}}$ & $174.8^{\mathrm{a}}$ & $63.9^{a b c}$ & $73.0^{\mathrm{a}}$ \\
\hline \multirow[t]{4}{*}{20} & V. atropurpurea & Atropurpurea & $136.9^{\mathrm{ab}}$ & $185.9^{\mathrm{a}}$ & $62.2^{\mathrm{abcd}}$ & $66.5^{\mathrm{ab}}$ \\
\hline & & Mean & 103.4 & 114.2 & 59.3 & 53.8 \\
\hline & & CV (\%) & 13.14 & 13.42 & 11.13 & 11.44 \\
\hline & & $R^{2}$ & 0.92 & 0.94 & 0.71 & 0.86 \\
\hline
\end{tabular}

Means followed by a common superscript letters within a column are not significantly different from each other at $P<0.05$

\section{Biomass production rate and herbage yield}

The biomass production rate and forage dry matter yield of vetch species were also highly determined by environmental and genetic variability. Higher biomass production rate and forage dry matter yield were recorded at Ginchi than Holetta. Biomass production rate for vetch species showed significant $(P<0.05)$ difference at both locations and ranged from 12.8 to $50.3 \mathrm{~kg} \mathrm{ha}^{-1}$ day $^{-1}$ at Holetta and 15.4 to $63.2 \mathrm{~kg} \mathrm{ha}^{-1}$ day $^{-1}$ at Ginchi (Table 8). A higher rate was recorded for Vicia villosa and Vicia sativa at Holetta and Ginchi, respectively. On the other extreme, Vicia atropurpurea had significantly lower $(P<0.05)$ rate than all species except Vicia dasycarpa at both testing locations. On the other hand, accessions of vetch species were not significant $(P>0.05)$ for biomass production rate at both locations (Table 9). Vicia narbonensis is early-maturing vetch species, and among its accessions, 2387 and 2376 had the highest and lowest biomass production rate, respectively, at both locations. Vicia sativa is another early-maturing vetch species, and its accessions 64266 and 61039 had the highest and lowest biomass production rate, respectively. Generally, the
Table 8 Least square means for biomass production rate (kg ha-1 day $^{-1}$ ) and forage dry matter yield at forage harvest of five vetch species grown at Holetta and Ginchi

\begin{tabular}{lllllr}
\hline Species & \multicolumn{2}{l}{$\begin{array}{l}\text { Biomass production } \\
\text { rate }\end{array}$} & & \multicolumn{2}{l}{ Forage DM yield } \\
\cline { 6 - 6 } \cline { 5 - 6 } & Holetta & Ginchi & & Holetta & Ginchi \\
\hline Vicia sativa & $47.3^{\mathrm{ab}}$ & $63.2^{\mathrm{a}}$ & & $5.05^{\mathrm{a}}$ & $6.79^{\mathrm{a}}$ \\
Vicia villosa & $50.3^{\mathrm{a}}$ & $50.6^{\mathrm{a}}$ & & $5.84^{\mathrm{a}}$ & $7.62^{\mathrm{a}}$ \\
Vicia narbonensis & $47.8^{\mathrm{ab}}$ & $61.7^{\mathrm{a}}$ & & $1.39^{\mathrm{b}}$ & $1.99^{\mathrm{b}}$ \\
Vicia dasycarpa & $29.3^{\mathrm{bc}}$ & $40.7^{\mathrm{ab}}$ & & $5.46^{\mathrm{a}}$ & $6.89^{\mathrm{a}}$ \\
Vicia atropurpurea & $12.8^{\mathrm{c}}$ & $15.4^{\mathrm{b}}$ & & $5.09^{\mathrm{a}}$ & $7.14^{\mathrm{a}}$ \\
Mean & 37.5 & 46.3 & & 4.56 & 6.09 \\
CV (\%) & 16.44 & 15.79 & & 21.12 & 21.14 \\
$R^{2}$ & 0.25 & 0.21 & & 0.84 & 0.74
\end{tabular}

Means followed by a common superscript letters within a column are not significantly different from each other at $P<0.05$

$\diamond=$ Log transformation

highest biomass production rate was recorded for accession 64266 ( $V$. sativa), which had 60.4 and $86.3 \mathrm{~kg} \mathrm{ha}^{-1}$ day $^{-1}$ at Holetta and Ginchi, respectively. On the other 
Table 9 Average biomass production rate $\left(\mathrm{kg} \mathrm{ha}^{-1}\right.$ day $\left.^{-1}\right)$ and DM yield (t/ha) of twenty accessions of vetch species grown at Holetta and Ginchi

\begin{tabular}{|c|c|c|c|c|c|c|}
\hline \multirow[t]{2}{*}{ Nos. } & \multirow[t]{2}{*}{ Species } & \multirow[t]{2}{*}{ Accessions } & \multicolumn{2}{|c|}{ Biomass production rate } & \multicolumn{2}{|c|}{ Total DM yield } \\
\hline & & & Holetta & Ginchi & Holetta & Ginchi \\
\hline 1 & Vicia sativa & 64266 & 60.4 & 86.3 & $5.65^{\mathrm{ab}}$ & $6.52^{\mathrm{ab}}$ \\
\hline 2 & V. sativa & 61904 & 46.9 & 63.1 & $5.96^{\mathrm{ab}}$ & $6.13^{b}$ \\
\hline 3 & V. sativa & 61744 & 53.5 & 75.5 & $5.25^{\mathrm{ab}}$ & $9.04^{\mathrm{a}}$ \\
\hline 4 & V. sativa & 61509 & 49.6 & 67.0 & $5.10^{\mathrm{ab}}$ & $7.79^{\mathrm{ab}}$ \\
\hline 5 & V. sativa & 61039 & 28.5 & 32.3 & $3.76^{b}$ & $8.38^{\mathrm{ab}}$ \\
\hline 6 & V. sativa & 61212 & 44.7 & 55.2 & $4.57^{\mathrm{ab}}$ & $2.84^{c}$ \\
\hline 7 & V. villosa & 2565 & 46.7 & 49.5 & $5.24^{\mathrm{ab}}$ & $5.44^{\mathrm{ab}}$ \\
\hline 8 & V. villosa & 2450 & 49.2 & 52.6 & $4.68^{a b}$ & $7.73^{\mathrm{ab}}$ \\
\hline 9 & V. villosa & 2424 & 53.7 & 60.7 & $7.48^{\mathrm{a}}$ & $8.66^{\mathrm{ab}}$ \\
\hline 10 & V. villosa & 2438 & 57.0 & 37.2 & $4.70^{\mathrm{ab}}$ & $8.60^{\mathrm{ab}}$ \\
\hline 11 & V. villosa & 2434 & 45.3 & 55.7 & $6.98^{\mathrm{a}}$ & $8.11^{\mathrm{ab}}$ \\
\hline 12 & V. villosa & 2446 & 49.8 & 47.9 & $5.96^{\mathrm{ab}}$ & $7.16^{\mathrm{ab}}$ \\
\hline 13 & V.narbonensis & 2384 & 40.0 & 45.1 & $1.46^{\mathrm{C}}$ & $2.21^{c}$ \\
\hline 14 & V. narbonensis & 2387 & 64.2 & 73.9 & $1.49^{c}$ & $1.87^{c}$ \\
\hline 15 & V.narbonensis & 2376 & 36.2 & 60.9 & $1.06^{\mathrm{C}}$ & $1.76^{c}$ \\
\hline 16 & V. narbonensis & 2392 & 46.3 & 61.2 & $1.47^{c}$ & $1.99^{c}$ \\
\hline 17 & V.narbonensis & 2380 & 52.3 & 67.1 & $1.44^{c}$ & $2.15^{c}$ \\
\hline 18 & V. dasycarpa & Namoi & 28.3 & 31.3 & $4.83^{\mathrm{ab}}$ & $7.30^{\mathrm{ab}}$ \\
\hline 19 & V. dasycarpa & Lana & 30.4 & 50.0 & $6.09^{\mathrm{ab}}$ & $6.48^{\mathrm{ab}}$ \\
\hline \multirow[t]{4}{*}{20} & V. atropurpurea & Atropurpurea & 12.78 & 15.4 & $5.09^{a b}$ & $7.14^{\mathrm{ab}}$ \\
\hline & & Mean & 44.8 & 54.4 & 4.41 & 5.87 \\
\hline & & CV (\%) & 51.42 & 52.44 & 20.05 & 16.89 \\
\hline & & $R^{2}$ & 0.36 & 0.35 & 0.9 & 0.88 \\
\hline
\end{tabular}

Means followed by a common superscript letters within a column are not significantly different from each other at $P<0.05$

$\diamond=$ Log transformation

extreme, the lowest rate was recorded for atropurpurea (V. atropurpurea), which had 12.8 and $15.4 \mathrm{~kg} \mathrm{ha}^{-1}$ day $^{-1}$ at Holetta and Ginchi, respectively. Generally, early-maturing vetch species had comparatively higher biomass production rate, while late-maturing species had lower biomass production rate at both locations. Similarly, accessions of early-maturing species had comparatively higher biomass production rate, while latematuring accessions had lower biomass production rate at both locations. Tamene [26] reported that there was significant positive gain in biomass production rate and strong association between grain yield and biomass production rate in faba bean. Generally, intermediate-tolate-maturing vetch species gave relatively better forage DM yield than early-maturing vetch species at both locations. This could be explained in terms of the longer duration of growth which probably enabled the late-maturing varieties to take full advantage of the better growing conditions [27]. Fekede [28] also reported that intermediateto-late-maturing oats varieties gave comparatively higher forage yield than the early-maturing oats varieties.
Forage DM yields were different $(P<0.05)$ at both locations and ranged from 1.39 to 5.84 and 1.99 to $7.62 \mathrm{tha}^{-1}$ at Holetta and Ginchi, respectively (Table 8). Among vetch species, dry biomass forage yield varied across the testing sites at forage harvesting stage. The higher forage DM yield was obtained at Ginchi than Holetta. Accordingly, on average, the species gave $33.6 \%$ more herbage DM yield at Ginchi compared to Holetta. Vicia villosa gave relatively higher forage DM yield followed by Vicia dasycarpa, Vicia atropurpurea, Vicia sativa and Vicia narbonensis at Holetta. At Ginchi, Vicia villosa produced relatively higher forage DM yield followed by Vicia atropurpurea, Vicia dasycarpa, Vicia sativa and Vicia narbonensis. On the other hand, forage DM yield of vetch accessions showed significant $(P<0.05)$ difference at both locations (Table 9). At Holetta, accession 2424 ( $V$. sativa) gave relatively higher DM yield than the remaining accessions, while at Ginchi, accession 61744 ( $V$. sativa) was the highest yielder. Among vetch accessions, dry biomass forage yield varied across the testing sites. The higher forage DM yield was obtained at Ginchi than Holetta. 
Generally, intermediate-to-late-maturing accessions of vetch species gave relatively better forage DM yield than early-maturing accessions of vetch species at both locations. Getnet and Ledin [15] reported that soil type was found to be the most important factor affecting biomass yield, and hence, herbage production on the well-drained red soil was almost double compared to the black soil. However, in this study, comparatively higher biomass yield was obtained on black soil (Ginchi) than red soil (Holetta) during the cropping season. Because forage crops of this study were sown on camber bed which minimized the water-logging problem of vertisol and resulted relatively in higher biomass yield.

\section{Grain filling period and total grain sink filling rate}

The grain filling period of vetch species differed significantly $(P<0.05)$ at both locations, ranging from 46.9 to 72.4 days with a mean of 56.2 days and from 70.0 to 79.8 days with a mean of 76.1 days at Holetta and Ginchi, respectively (Table 10). The highest grain filling period was recorded for Vicia villosa at Holetta and Vicia sativa at Ginchi, whereas the lowest period was recorded for Vicia sativa and Vicia narbonensis at Holetta and Ginchi, respectively. In general, most of the species started flowering early and had shorter grain filling period. However, some of vetch species in this study showed early to start flowering, but took longer period to fill the grain. Location had an effect $(P<0.05)$ on grain sink filling rate of vetch species, which ranged from 7.2 to $16.4 \mathrm{~kg} \mathrm{ha}^{-1}$ day $^{-1}$ with a mean of $11.4 \mathrm{~kg} \mathrm{ha}^{-1} \mathrm{day}^{-1}$ at Holetta and from 26.0 to $41.0 \mathrm{~kg} \mathrm{ha}^{-1}$ day $^{-1}$ with a mean of $31.6 \mathrm{~kg} \mathrm{ha}^{-1}$ day $^{-1}$ at Ginchi (Table 10). The rate was the highest for Vicia sativa $\left(16.4 \mathrm{~kg} \mathrm{ha}^{-1} \mathrm{day}^{-1}\right)$ at Holetta and for Vicia narbonensis $\left(41.0 \mathrm{~kg} \mathrm{ha}^{-1} \mathrm{day}^{-1}\right)$ at Ginchi, whereas the lowest rate

\begin{tabular}{|c|c|c|c|c|}
\hline \multirow[t]{2}{*}{ Species } & \multicolumn{2}{|c|}{ Grain filling period } & \multicolumn{2}{|c|}{$\begin{array}{l}\text { Grain sink filling } \\
\text { rate }\end{array}$} \\
\hline & Holetta & Ginchi & Holetta & Ginchi \\
\hline Vicia sativa & $46.9^{c}$ & $79.8^{\mathrm{a}}$ & $16.4^{\mathrm{a}}$ & $33.9^{\mathrm{a}}$ \\
\hline Vicia villosa & $72.4^{\mathrm{a}}$ & $78.6^{\mathrm{a}}$ & $10.2^{b}$ & $29.1^{\mathrm{ab}}$ \\
\hline Vicia narbonensis & $56.9^{b}$ & $70.0^{b}$ & $7.2^{c}$ & $41.0^{\mathrm{a}}$ \\
\hline Vicia dasycarpa & $51.8^{b c}$ & $78.8^{\mathrm{a}}$ & $13.6^{\mathrm{ab}}$ & $26.0^{b}$ \\
\hline Vicia atropurpurea & $53.0^{\mathrm{bc}}$ & $73.3^{\mathrm{ab}}$ & $9.5^{\mathrm{bc}}$ & $27.8^{\mathrm{ab}}$ \\
\hline Mean & 56.2 & 76.1 & 11.4 & 31.6 \\
\hline CV (\%) & 12.85 & 8.0 & 13.17 & 8.86 \\
\hline$R^{2}$ & 0.68 & 0.35 & 0.29 & 0.19 \\
\hline
\end{tabular}

Means followed by a common superscript letters within a column are not significantly different from each other at $P<0.05$

$\diamond=$ Log transformation was recorded for Vicia narbonensis $\left(7.2 \mathrm{~kg} \mathrm{ha}^{-1} \mathrm{day}^{-1}\right)$ at Holetta and for Vicia dasycarpa (27.8 $\mathrm{kg} \mathrm{ha}^{-1}$ day $\left.^{-1}\right)$ at Ginchi. Grain sink filling rate is directly related to the seed yield. On the other hand, grain filling period and grain sink filling rate significantly $(P<0.05)$ vary among accessions of vetch species at both locations (Table 11). The highest grain filling period was recorded for accession 2424 ( $V$. villosa) at Holetta and accession 64266 ( $V$. sativa) at Ginchi, whereas the lowest period was recorded for Vicia narbonensis accessions 2376 and 2387 at Holetta and Ginchi, respectively. The highest and lowest grain sink filling rates were recorded for accession $61509(\mathrm{~V}$. sativa) and 2387 ( $V$. narbonensis) at Holetta and accession 2380 (V. narbonensis) and 61039 (V. sativa) at Ginchi, respectively. Grain sink filling rate is directly related to the seed yield. Improvement in grain sink filling rate is an important task for maximum seed yield production of any crop. According to Yifru [29], tef grain yield improvement over 35 years of research has been associated mostly with corresponding increase in panicle grain sink filling rate and panicle yield. Tamene [26] also reported that sizeable improvement was made in economic growth rate and biomass production rate in faba bean breeding. Westgate [30] for some cereals and Wang et al. [31] in tufted vetch reported that the effect of environmental stress reduced the period and duration of seed filling as a consequence, poor seed size and weight resulted. The consequences of stress on grain filling are associated with leaf senescence and with a decrease in metabolic activity of the embryo and endosperm cells which promotes the premature desiccation of seed [32, 33].

\section{Seed yield and thousand seed weight}

The seed yield of vetch species differed significantly $(P<0.05)$ at Holetta, but not at Ginchi, which ranged from 0.4 to $0.8 \mathrm{t} \mathrm{ha}^{-1}$ with a mean of $0.6 \mathrm{t} \mathrm{ha}^{-1}$ at Holetta and from 2.0 to $2.9 \mathrm{t} \mathrm{ha}^{-1}$ with a mean of $2.4 \mathrm{t} \mathrm{ha}^{-1}$ at Ginchi (Table 12). The highest seed yield was obtained from Vicia sativa $\left(0.8 \mathrm{t} \mathrm{ha}^{-1}\right)$ at Holetta and Vicia narbonensis $\left(2.9 \mathrm{t} \mathrm{ha}^{-1}\right)$ at Ginchi, whereas the lowest yield was obtained from Vicia narbonensis $\left(0.4 \mathrm{t} \mathrm{ha}^{-1}\right)$ at Holetta and Vicia atropurpurea $\left(2.0 \mathrm{t} \mathrm{ha}^{-1}\right)$ at Ginchi. On the other hand, seed yield differed significantly $(P<0.05)$ among the accessions of vetch species at both locations (Table 13). At Holetta, accession 61094 (V. sativa) and 2387 ( $V$. narbonensis) gave the highest and lowest seed yield, respectively. The highest seed yield was obtained from accession 2380 ( $V$. narbonensis), whereas the lowest from accession 61039 (V. sativa) at Ginchi. Generally, vech accessions showed higher seed yield and thousand seed weight at Ginchi than Holetta. 
Table 11 Average grain filling period (days) and grain sink filling rate $\left(\mathrm{kg} \mathrm{ha}^{-1}\right.$ day $\left.^{-1}\right)$ of twenty accessions of vetch species grown at Holetta and Ginchi

\begin{tabular}{|c|c|c|c|c|c|c|}
\hline \multirow[t]{2}{*}{ Nos. } & \multirow[t]{2}{*}{ Species } & \multirow[t]{2}{*}{ Accessions } & \multicolumn{2}{|c|}{ Grain filling period } & \multicolumn{2}{|c|}{ Grain sink filling rate } \\
\hline & & & Holetta & Ginchi & Holetta & Ginchi \\
\hline 1 & Vicia sativa & 64266 & $50.3^{b c}$ & $86.3^{\mathrm{a}}$ & $11.0^{\mathrm{abc}}$ & $32.6^{\mathrm{bcd}}$ \\
\hline 2 & V. sativa & 61904 & $50.7^{\mathrm{bc}}$ & $85.7^{\mathrm{a}}$ & $19.8^{\mathrm{ab}}$ & $32.47^{\mathrm{bcd}}$ \\
\hline 3 & V. sativa & 61744 & $43.7^{c}$ & $81.0^{\mathrm{abcd}}$ & $13.6^{\mathrm{abc}}$ & $35.5^{\mathrm{abc}}$ \\
\hline 4 & V. sativa & 61509 & $43.7^{c}$ & $81.7^{\mathrm{abc}}$ & $21.7^{\mathrm{a}}$ & $38.0^{\mathrm{abc}}$ \\
\hline 5 & V. sativa & 61039 & $44.0^{c}$ & $69.3^{\text {ef }}$ & $14.9^{\mathrm{abc}}$ & $20.0^{d}$ \\
\hline 6 & V. sativa & 61212 & $49.0^{\mathrm{bc}}$ & $74.7^{\text {bcdef }}$ & $17.2^{a b}$ & $44.6^{\mathrm{ab}}$ \\
\hline 7 & V. villosa & 2565 & $63.7^{\mathrm{ab}}$ & $83.7^{\mathrm{ab}}$ & $14.8^{\mathrm{abc}}$ & $33.0^{\mathrm{bcd}}$ \\
\hline 8 & V. villosa & 2450 & $75.3^{\mathrm{a}}$ & $80.0^{\mathrm{abcd}}$ & $8.8^{\mathrm{bcd}}$ & $28.3^{\mathrm{bcd}}$ \\
\hline 9 & V. villosa & 2424 & $76.0^{\mathrm{a}}$ & $78.7^{\text {abcde }}$ & $11.7^{\mathrm{abc}}$ & $30.4^{\mathrm{bcd}}$ \\
\hline 10 & V. villosa & 2438 & $74.0^{\mathrm{a}}$ & $75.7^{\mathrm{abcdef}}$ & $6.2^{c d}$ & $27.8^{\mathrm{bcd}}$ \\
\hline 11 & V. villosa & 2434 & $74.7^{\mathrm{a}}$ & $76.7^{\text {abcdef }}$ & $10.7^{a b c}$ & $29.9^{b c d}$ \\
\hline 12 & V. villosa & $244 a 6$ & $70.7^{\mathrm{a}}$ & $77.0^{\mathrm{abcdef}}$ & $8.8^{\mathrm{abcd}}$ & $25.3^{\mathrm{cd}}$ \\
\hline 13 & V.narbonensis & 2384 & $60.3^{\mathrm{ab}}$ & $72.0^{\text {cdef }}$ & $7.9^{\mathrm{bcd}}$ & $43.1^{\mathrm{ab}}$ \\
\hline 14 & V. narbonensis & 2387 & $59.7^{\mathrm{ab}}$ & $68.0^{f}$ & $4.6^{d}$ & $32.2^{\mathrm{bcd}}$ \\
\hline 15 & V. narbonensis & 2376 & $45.3^{c}$ & $68.7^{\mathrm{ef}}$ & $6.9^{\mathrm{cd}}$ & $43.3^{\mathrm{ab}}$ \\
\hline 16 & V. narbonensis & 2392 & $60.0^{\mathrm{ab}}$ & $70.3^{\text {def }}$ & $6.2^{\mathrm{cd}}$ & $26.5^{\mathrm{bcd}}$ \\
\hline 17 & V.narbonensis & 2380 & $59.3^{\mathrm{ab}}$ & $71.0^{\text {def }}$ & $10.4^{\mathrm{abcd}}$ & $60.0^{\mathrm{a}}$ \\
\hline 18 & V. dasycarpa & Namoi & $51.7^{\mathrm{bc}}$ & $82.3^{a b c}$ & $12.8^{\mathrm{abc}}$ & $27.1^{\mathrm{bcd}}$ \\
\hline 19 & V. dasycarpa & Lana & $52.0^{b c}$ & $75.3^{\mathrm{abcdef}}$ & $14.4^{\mathrm{abc}}$ & $25.0^{\mathrm{cd}}$ \\
\hline \multirow[t]{4}{*}{20} & V. atropurpurea & Atropurpurea & $53.0^{\mathrm{bc}}$ & $73.3^{\text {bcdef }}$ & $9.5^{\mathrm{abcd}}$ & $27.8^{\mathrm{bcd}}$ \\
\hline & & Mean & 57.9 & 76.6 & 11.6 & 33.1 \\
\hline & & CV (\%) & 3.39 & 1.6 & 21.59 & 7.60 \\
\hline & & $R^{2}$ & 0.75 & 0.64 & 0.57 & 0.57 \\
\hline
\end{tabular}

Means followed by a common superscript letters within a column are not significantly different from each other at $P<0.05$

$\checkmark=$ Log transformation

Table 12 Least square means for seed yield $\left(\mathrm{t} \mathrm{ha} \mathrm{h}^{-1}\right.$ ) and thousand seed weight $(g)$ of five vetch species at Holetta and Ginchi

\begin{tabular}{lccccc}
\hline Species & \multicolumn{2}{l}{ Seed yield $\left(\mathbf{t ~ h a}^{\mathbf{- 1}}\right)^{\star}$} & & \multicolumn{2}{l}{$\begin{array}{l}\text { Thousand seed } \\
\text { weight }(\mathbf{g})^{\star}\end{array}$} \\
\cline { 2 - 3 } \cline { 6 - 6 } & Holetta & Ginchi & & Holetta & Ginchi \\
\hline Vicia sativa & $0.8^{\mathrm{a}}$ & 2.7 & & $49.4^{\mathrm{b}}$ & $54.7^{\mathrm{b}}$ \\
Vicia villosa & $0.7^{\mathrm{a}}$ & 2.3 & & $46.2^{\mathrm{b}}$ & $42.5^{\mathrm{b}}$ \\
Vicia narbonensis & $0.4^{\mathrm{b}}$ & 2.9 & & $222.8^{\mathrm{a}}$ & $242.2^{\mathrm{a}}$ \\
Vicia dasycarpa & $0.7^{\mathrm{a}}$ & 2.1 & & $44.1^{\mathrm{b}}$ & $43.4^{\mathrm{b}}$ \\
Vicia atropurpurea & $0.5^{\mathrm{ab}}$ & 2.0 & & $46.1^{\mathrm{b}}$ & $48.8^{\mathrm{b}}$ \\
Mean & 0.6 & 2.4 & & $81.7^{\prime}$ & 86.3 \\
CV (\%) & 12.42 & 5.86 & & 24.51 & 24.99 \\
$R^{2}$ & 0.32 & 0.12 & & 0.93 & 0.93 \\
\hline
\end{tabular}

Means followed by a common superscript letters within a column are not significantly different from each other at $P<0.05$

$\checkmark=$ Log transformation
Thousand seed weight of vetch species showed a significant $(P<0.05)$ difference at both locations, which ranged from 44.1 to $222.8 \mathrm{~g}$ with a mean of $81.7 \mathrm{~g}$ at Holetta and from 42.5 to $242.2 \mathrm{~g}$ with a mean of $86.3 \mathrm{~g}$ at Ginchi (Table 12). The highest thousand seed weight was for Vicia narbonensis at both locations, whereas the lowest for Vicia dasycarpa and Vicia villosa at Holetta and Ginchi, respectively. Though Vicia narbonensis had the highest thousand seed weight, its seed yield was relatively lower due to lower establishment performance at Holetta. On the other hand, accessions of vetch species also varied significantly $(P<0.05)$ in thousand seed weight at both locations (Table 13). The highest thousand seed weight was recorded for accession 2376 ( $V$. narbonensis), whereas the lowest was recorded for accession 61039 ( V. sativa) at both locations. The difference could be due to the inherent variation in seed size complemented with the environmental and soil conditions. Unless the establishment performance is poor, species with high thousand seed weight has higher seed yield. Getnet et al. [25] and Fekede [28] also reported that most 
Table 13 Average seed yield $\left(\mathrm{t} \mathrm{ha}{ }^{-1}\right.$ ) and thousand seed weight $(\mathrm{g})$ of twenty accessions of vetch species grown at Holetta and Ginchi

\begin{tabular}{|c|c|c|c|c|c|c|}
\hline \multirow[t]{2}{*}{ Nos. } & \multirow[t]{2}{*}{ Species } & \multirow[t]{2}{*}{ Accessions } & \multicolumn{2}{|c|}{ Seed yield } & \multicolumn{2}{|c|}{ Thousand seed weight } \\
\hline & & & Holetta & Ginchi & Holetta & Ginchi \\
\hline 1 & Vicia sativa & 64266 & $0.6^{\mathrm{abcd}}$ & $2.8^{\mathrm{abcd}}$ & $54.7^{d}$ & $61.3^{f}$ \\
\hline 2 & V. sativa & 61904 & $1.0^{\mathrm{a}}$ & $2.8^{\mathrm{abcd}}$ & $54.3^{d}$ & $60.2^{\mathrm{fg}}$ \\
\hline 3 & V. sativa & 61744 & $0.6^{\mathrm{abcd}}$ & $2.9^{\mathrm{abcd}}$ & $46.0^{\mathrm{def}}$ & $56.5^{9}$ \\
\hline 4 & V. sativa & 61509 & $0.9^{\mathrm{a}}$ & $3.1^{\mathrm{abc}}$ & $54.7^{d}$ & $67.7^{e}$ \\
\hline 5 & V. sativa & 61039 & $0.7^{a b c}$ & $1.4^{\mathrm{e}}$ & $37.9^{f}$ & $26.4^{k}$ \\
\hline 6 & V. sativa & 61212 & $0.8^{\mathrm{ab}}$ & $3.2^{\mathrm{ab}}$ & $48.8^{\mathrm{de}}$ & $56.0^{9}$ \\
\hline 7 & V. villosa & 2565 & $0.8^{\mathrm{ab}}$ & $2.8^{\mathrm{abcd}}$ & $46.2^{\text {def }}$ & $42.6^{i}$ \\
\hline 8 & V. villosa & 2450 & $0.7^{\mathrm{abc}}$ & $2.3^{\text {bcde }}$ & $46.5^{\text {de }}$ & $39.1^{j}$ \\
\hline 9 & V. villosa & 2424 & $0.9^{\mathrm{ab}}$ & $2.4^{\mathrm{bcd}}$ & $47.0^{\mathrm{de}}$ & $41.7^{\mathrm{ij}}$ \\
\hline 10 & V. villosa & 2438 & $0.5^{\mathrm{abcd}}$ & $2.1^{\text {bcde }}$ & $46.2^{\text {def }}$ & $42.4^{i}$ \\
\hline 11 & V. villosa & 2434 & $0.8^{\mathrm{ab}}$ & $2.3^{\text {bcde }}$ & $46.6^{\text {de }}$ & $44.0^{i}$ \\
\hline 12 & V. villosa & 2446 & $0.6^{\mathrm{abc}}$ & $1.9^{\text {cde }}$ & $44.8^{\mathrm{def}}$ & $44.9^{i}$ \\
\hline 13 & V. narbonensis & 2384 & $0.5^{\mathrm{abcd}}$ & $3.1^{\mathrm{abcd}}$ & $199.8^{b c}$ & $243.9^{c}$ \\
\hline 14 & V.narbonensis & 2387 & $0.3^{d}$ & $2.2^{\text {bcde }}$ & $248.4^{\mathrm{ab}}$ & $201.2^{d}$ \\
\hline 15 & V. narbonensis & 2376 & $0.3^{c d}$ & $3.0^{\mathrm{abcd}}$ & $258.0^{\mathrm{a}}$ & $301.6^{\mathrm{a}}$ \\
\hline 16 & V.narbonensis & 2392 & $0.4^{\mathrm{bcd}}$ & $1.9^{\text {cde }}$ & $177.3^{c}$ & $192.9^{d}$ \\
\hline 17 & V. narbonensis & 2380 & $0.6^{\mathrm{abcd}}$ & $4.2^{\mathrm{a}}$ & $230.6^{\mathrm{ab}}$ & $271.7^{d}$ \\
\hline 18 & V. dasycarpa & Namoi & $0.7^{\mathrm{abc}}$ & $2.2^{\text {bcde }}$ & $45.7^{\text {def }}$ & $44.1^{i}$ \\
\hline 19 & V. dasycarpa & Lana & $0.8^{\mathrm{abc}}$ & $1.9^{\mathrm{de}}$ & $42.4^{e f}$ & $42.6^{i}$ \\
\hline \multirow[t]{4}{*}{20} & V. atropurpurea & Atropurpurea & $0.5^{\mathrm{abcd}}$ & $2.0^{\text {bcde }}$ & $46.1^{\text {def }}$ & $48.8^{h}$ \\
\hline & & Mean & 0.6 & 2.5 & 91.1 & 96.5 \\
\hline & & CV (\%) & 12.53 & 4.75 & 2.96 & 1.03 \\
\hline & & $R^{2}$ & 0.51 & 0.58 & 0.98 & 1.00 \\
\hline
\end{tabular}

Means followed by a common superscript letters within a column are not significantly different from each other at $P<0.05$

$\checkmark=$ Log transformation

of the oats varieties with high grain yield showed higher 1000 kernel weight. In general, vetch species ( $V$. narbonensis and $V$. sativa) which have erect growth habit and early maturing had comparatively higher thousand seed weight than creeping growth habit and intermediate-tolate-maturing vetch species. The difference could be due to the inherent variation in seed size complemented with the environmental and soil conditions. This agronomic trait is important for seed rate determination of vetch species. Fekede [28] also reported that thousand seed weight has got practical significance in estimating seeding rate for each oat variety in order to ensure that equal number of seeds could be sown per unit area.

\section{Conclusion}

Average total DM yield and its botanical fraction yields were higher at Ginchi than Holetta. Vicia villosa gave relatively higher total DM yield (5.8 and $7.6 \mathrm{t} \mathrm{ha}^{-1}$ ), whereas Vicia narbonensis gave the lowest total DM yield (1.4 and $2.0 \mathrm{t} \mathrm{ha}^{-1}$ ) at Holetta and Ginchi, respectively, at forage harvesting stage. Vicia sativa $\left(0.8 \mathrm{t} \mathrm{ha}^{-1}\right)$ and Vicia narbonensis $\left(2.9 \mathrm{t} \mathrm{ha}^{-1}\right)$ gave the highest seed yield at Holetta and Ginchi, respectively. Vicia narbonensis had shorter vegetative and grain filling period, whereas Vicia atropurpurea and Vicia villosa had longer vegetative and grain filling period, respectively. Generally, vetch species and their accessions varied in most measured parameters. These differences are very important to select the type of companion crops and methods of integration to improve yields of both crops (food and forage) without significant effect of one on the other. Compatible crops can give higher yields per unit area when proper management and selection of crops and methods were employed during integration. The overall generated information on vetch species and their accessions in this study is very important for integration of vetch with cereals and nonlegumes forage crops. Among vetch species and their accessions, Vicia villosa, Vicia dasycarpa and Vicia atropurpurea species and their accessions have a potential for integration with other crops. However, the selected species and their accessions should be tested by integrating with different crops (food and forage) over locations and 
years to come up with better recommendation to solve the feed problem of the Ethiopian highlands.

\section{Abbreviations}

DM: dry matter; GDP: gross domestic product; HARC: Holetta agricultural research center; $\mathrm{pH}$ : power of hydrogen; $\mathrm{CEC}$ : cation-exchange capacity; OM: organic matter.

\section{Authors' contributions}

GK initiated the research, wrote the research proposal, conducted the research, did data collection and analysis and wrote the manuscript. The author read and approved the final manuscript.

\section{Acknowledgements}

The author is grateful for the financial support provided by the livestock process of Holetta Agricultural Research Center (HARC) to undertake the experiment. My special gratitude also goes to forage and pasture research colleagues at HARC for their technical and material support throughout the entire work.

\section{Competing interests}

The author declares that there have no competing interests.

\section{Availability of data and materials \\ Not applicable.}

\section{Consent for publication}

Not applicable.

\section{Ethics approval and consent to participate}

Not applicable.

\section{Funding}

The author would like to acknowledge the Ethiopian Institute of Agricultural Research.

\section{Publisher's Note}

Springer Nature remains neutral with regard to jurisdictional claims in published maps and institutional affiliations.

Received: 4 October 2018 Accepted: 7 December 2018

Published online: 12 December 2018

\section{References}

1. Zinash S, Aschalew T, Alemu Y, Azage T. Status of livestock research and development in the highlands of Ethiopia. In: Wall PC (ed) Chapter 1. Wheat and weeds: food and feed. Proceeding of two stockholder workshops, 10-11 Oct. 2000. Mexico City, Mexico. 2001. p. 227-50.

2. Alemayehu M. Rangelands biodiversity: concepts, approaches, and the way forward. Ethiopia: Addis Ababa; 2004.

3. Ayele S, Assegid W, Jabbar MA, Ahmed MM, Belachew H. Livestock marketing in Ethiopia. A review of structure, performance and development initiatives. Socio-economic and Policy Research Working Paper 52. ILRI, Nairobi, Kenya. 2002.

4. FAO. Livestock sector brief, Ethiopia. Livestock Information, Sector Analysis and Policy Branch, AGAL. 2003.

5. Getachew F. A review of the small scale dairy sector-Ethiopia. FAO prevention of food losses programme: milk and dairy products, post-harvest, losses and food safety in Sub-Saharan Africa and the Near East. 2003.

6. Seyoum B, Zinash S. Chemical composition, in vitro digestibility and energy value of Ethiopian feedstuffs. In: Proceedings of the 3rd annual conference of the ethiopian society of animal production, 27-29 April 1995, Addis Ababa, Ethiopia. 1995. p. 307-11.
7. Assefa A. Farm management in mixed crop livestock systems in the Northern Highlands of Ethiopia. Ph.D. Thesis, Wageningen Agricultural University, Wageningen, The Netherlands. 2005.

8. Tsige Y. Livestock feed security and associated impacts on sustainable agricultural development. In: Proceedings of the 7th annual conference of ethiopian society of animal production (ESAP), Addis Ababa, Ethiopia, 26-27 May 1999. 2000. p. 51-61.

9. Hindrichsen IK, Osuji PO, Odenyo AA, Madsen J, Hvelplund T. Effect of supplementation of maize stover with foliage of various tropical multipurpose trees and Lablab purpureus on intake, rumen fermentation, digesta kinetics and microbial protein supply of sheep. Anim Feed Sci Technol. 2004;113:83-96.

10. Muriuki HG. A review of the small-scale dairy sector-Kenya. In: Milk and dairy products, post-harvest losses and food safety in Sub- Saharan Africa and the Near East. FAO. Rome. 2003.

11. Berhanu G, Ahmed MM, Ehui SK. Determinants of adoption of improved foraged technologies in crop-livestock mixed systems: evidence from the highlands of Ethiopia. Trop Grassl. 2003;37:262-73.

12. IAR. Departement of animal science pasture and forage team progress report, April 1984 t o march 1985 Addis Ababa. 1986.

13. IAR. Hand book on pasture and forage crops for animal feeding in Ethiopia. 1st ed. Addis Ababa: IAR; 1980.

14. Seyoum B. Evaluation of nutritive values of herbaceous legumes, browse species and oil seed cakes using chemical analysis. In vitro digestibility and nylon bag technique. M.Sc. Thesis. Alemaya university of Agriculture, Ethiopia. 1994.

15. Getnet A, Ledin I. Effect of variety, soil type and fertilizer on the establishment, growth, forage yield and voluntary intake by cattle of oats and vetches cultivated in pure and stands and mixtures. Anim Feed Sci Technol. 2001;92:95-111.

16. EIAR. Holetta Agricultural Research Center/HARC/progress report 2005/06. EIAR/HARC. 2005.

17. Gemechu K. Phenotypic diversity for biological nitrogen fixation in Abyssinian field pea (Pisum sativum var. abyssinicum) germplasm accession. Report on independent study for Ph.D. Addis Ababa University Science Faculty. 2007.

18. Getachew A, Abraham F, Gemechu K, Mussa J. Chickpea varietal responses to drainage on vertisol of Ginchi highlands of Ethiopia. Ethiop Soc Soil Sci, Ethiop J Natl Resour. 2007;2:191-207.

19. Getnet A. Feed resource assessment and evaluation of forage yield, quality and intake of oats and vetches grown in the highlands of Ethiopia. M.Sc. Thesis. Swedish University of Agricultural Science. Uppsala. 1999. p. $1-19$.

20. SAS. SAS/STAT guide for personal computers, version 9.0 editions. Cary, NC: SAS Institute Inc.; 2002.

21. Gomez KA, Gomez AA. Statistical procedure for agricultural research. 2nd ed. Los Baños: International Rice Research Institute, Wiley; 1984.

22. Marshner H. Mineral nutrition of higher plants. London: Academic Press; 1995.

23. Muluneh M. Effect of Rhizobium inoculation on nodulation, nitrogen fixation and yield of some annual forage legumes (Vicia spp.) on Nitisol and vertisol of the central highlands of Ethiopia. M.Sc. Thesis. Alemaya University of Agriculture, Ethiopia. 2006.

24. Mengel K, Kirkby EA. Principles of plant nutrition. Bern: International Potash Institute; 1987.

25. Getnet A, Tekleyohanes B, Lemma G, Mesfin D, Diriba G. Major herbaceous forage legumes: Some achievements in species and varietal evaluation in Ethiopia. In: Kemal A, Surendra SAB, Kenneni G, Rajendra M, Khaled M (eds.) Food and forage legumes of Ethiopia: progress and prospects. Proceedings of the work shop on food and forage legumes 22-26 September 2003. Addis Ababa, Ethiopia. 2003.

26. Tamene T. Genetic gain and morpho-agronomic basis of genetic improvement in grain yield potential achieved by faba bean breeding in Ethiopia. An M.Sc. thesis presented to the school of graduate studies of Hawassa University. 2008

27. Chia AJ. Forage production of triticale relative to other spring grains. Agron J. 1983;75:610-3.

28. Fekede F. Evaluation of potential forage production qualities of selected oats (Avena sativa L.) genotypes. M.Sc. Thesis. Alemaya University of Agriculture, Ethiopia. 2004. 
29. Yifru T. Genetic gain in grain yield potential and associated agronomic trait of tef (Eragrosis tef (Zucc.). Trotter). An M.Sc. thesis presented to the school of Graduate studies of Alemaya University. 1998.

30. Westgate ME. Water status and development of maize endosperm and embryo during drought. Crop Sci. 1994;34:76-83.

31. Wang YR, Mu C, Hou Y, Li X. Optimum harvest time of Vicia cracca L. in relation to high seed quality during pod development. Crop Sci. 2008;48:709-15.
32. Egli DB. Seed growth and development. In: Boote KJ, Bennett HM, Sinclair TR, Paulson GP, editors. Physiology and determination of crop yield. Madison: ASA, CSSA, SSS; 1994. p. 127-1148.

33. Lemke BM, Gibson LR, Knapp AD, Dixon PM, Moore KJ, Hintz R. Maximizing seed production in eastern gamagrass. Agronomy J. 2003;95:863-9.
Ready to submit your research? Choose BMC and benefit from:

- fast, convenient online submission

- thorough peer review by experienced researchers in your field

- rapid publication on acceptance

- support for research data, including large and complex data types

- gold Open Access which fosters wider collaboration and increased citations

- maximum visibility for your research: over $100 \mathrm{M}$ website views per year

At BMC, research is always in progress.

Learn more biomedcentral.com/submissions 